\title{
Correction to: Human Pluripotent Stem Cells for High-Throughput Drug Screening and Characterization of Small Molecules
}

\author{
Seungmi Ryu, Pei-Hsuan Chu, Claire Malley, John Braisted, \\ Pinar Ormanoglu, Ruili Huang, Misha Itkin, Zina Itkin, Paul Shinn, \\ Carleen Klumpp-Thomas, Sam Michael, Carlos A. Tristan, \\ Anton Simeonov, and Ilyas Singeç
}

Correction to:

Chapter "Human Pluripotent Stem Cells for High-Throughput Drug Screening and Characterization of Small Molecules" in K. Turksen, Methods in Molecular Biology, https://doi.org/10.1007/7651_2021_394

This chapter was inadvertently published with an error, the ninth point under 'Materials' section must read:

'Integrated stress response inhibitor Trans-ISRIB (R\&D Systems, cat. no. 5284): To prepare a $7 \mathrm{mM}(10,000 \mathrm{x}$ stock) solution of Trans-ISRIB, dissolve $10 \mathrm{mg}$ of Trans-ISRIB in $3.165 \mathrm{ml}$ of DMSO. Gently warm at $45-60{ }^{\circ} \mathrm{C}$ and vortex until completely dissolved. Store at $4{ }^{\circ} \mathrm{C}$ for up to a month or $-20{ }^{\circ} \mathrm{C}$ for up to 1 year.'

instead of:

'Integrated stress response inhibitor Trans-ISRIB (R\&D Systems, cat. no. 5284): To prepare a $7 \mathrm{mM}(10,000 \mathrm{x}$ stock) solution of Trans-ISRIB, dissolve $10 \mathrm{mg}$ of Trans-ISRIB in $31.65 \mathrm{ml}$ of DMSO. Gently warm at $45-60{ }^{\circ} \mathrm{C}$ and vortex until completely dissolved. Store at $4{ }^{\circ} \mathrm{C}$ for up to a month or $-20{ }^{\circ} \mathrm{C}$ for up to 1 year.' 